\title{
Cell-to-cell pollution reduction effectiveness of subsurface domestic treatment wetlands
}

\author{
David N. Steer $^{\text {a,* }}$, Lauchlan H. Fraser ${ }^{b}$, Beth A. Seibert ${ }^{c}$ \\ a Geology Department, The University of Akron, Akron, OH 44325-4101, USA \\ ${ }^{\mathrm{b}}$ Biology Department, The University of Akron, Akron, OH 44325-3908, USA \\ c Ottawa River Coalition, 3900 Campus Dr., Suite A, Lima, OH 45804-3596, USA
}

Received 8 February 2002; received in revised form 30 July 2004; accepted 5 August 2004

Available online 2 October 2004

\begin{abstract}
Quarterly water quality data from 1998 to 2003 for eight single-family domestic systems serving 2-7 people in Ohio, USA, were studied to determine the cell-to-cell and system wide pathogen reduction efficiency and effectiveness of these systems in meeting compliance standards. Two-cell domestic wastewater treatment systems displayed significant variability in their cell-to-cell performance that directly impacted the overall ability of systems to meet effluent compliance standards. Fecal coliform was effectively reduced $(\sim 99 \%)$ in these systems while two-thirds of the input biochemical oxygen demand was mitigated in each of the cells of these systems. Fecal coliform and biochemical oxygen demand were typically reduced below 2000 counts per $100 \mathrm{ml}$ and $15 \mathrm{mg} / \mathrm{l}$ (respectively) before discharge to surface waters. Total suspended solids were reduced by $\sim 80 \%$ overall with cell one retaining the majority of the solids $(\sim 70 \%)$. These systems discharged more than $18 \mathrm{mg} / \mathrm{l}$ of suspended solids in less than $5 \%$ of the samples thus displaying a very high compliance rate. Ammonia and total phosphorus were less effectively treated $(\sim 30-40 \%$ reductions in each cell) and exceeded standards $(1.5 \mathrm{mg} / \mathrm{l})$ more frequently. Analyses based on the number of occupants indicated that the two-cell design used here was most effective for smaller occupancy systems. More study is required to determine the value of this design for large occupancy systems. In the future, wetlands should be evaluated based on the total loads delivered to the watershed rather than by effluent concentrations.
\end{abstract}

(C) 2004 Elsevier Ltd. All rights reserved.

Keywords: Treatment wetlands; Efficiency; Pathogens; Effectiveness

\section{Introduction}

The use of wetlands to treat domestic wastewater has gained global attention in recent years (Bastian et al., 1987) because they are seen as a low-maintenance management strategy that is an alternative to traditional treatment systems (Kadlec and Knight, 1996). These natural systems are known to effectively mitigate a variety of pollutants (Wood, 1995; Nokes et al., 1999; Mitsch and Gosselink, 2000). The ability of wetland sys\footnotetext{
7611.

* Corresponding author. Tel.: +1 330972 2099; fax: +1 330972

E-mail address: steer@uakron.edu (D.N. Steer).
}

tems to effectively reduce total suspended solids, biochemical oxygen demand (Watson et al., 1990) and fecal coliform (Nokes et al., 1999; Neralla et al., 2000) are well established. Nitrogen (ammonia and total nitrogen) and phosphorus are processed with relatively low efficiency by most wetland systems (Nichols, 1983; Mann, 1990; Hammer and Knight, 1994; Urbanc-Bercic and Bulc, 1995; Cronk and Fennessy, 2001). Wastewater designs employing wetlands that discharge to the surface may be well suited for areas with poor drainage or hydric soils that limit effective use of traditional leach fields.

The systems discussed in this paper discharge to the surface and are considered non-point sources of pollution because of the small volumes of effluent and widely 
separated geographic locations involved. Surface discharging domestic wastewater wetland treatment systems in the US need to meet National Pollution Discharge Elimination Systems (NPDES) permit guidelines to be in compliance with pollution reduction goals implemented under the watershed Total Maximum Daily Loads (TMDL) program. The TMDL program involves establishment of maximum pollution loads for impaired river segments. The NPDES program focuses on improving water impaired by pollution and promoting wide-ranging solutions to the myriad of problems threatening water quality (USEPA, 2001). Regulatory guidelines in Ohio, USA that were established to comply with NPDES', lower several pathogen limits (OEPA, 1999: Table 1) and discourage off-lot discharge of any kind (OEPA, 2001). The effluent limits required by the household sewage disposal permitting system were derived from EPA guidance and regulations (USEPA, 2001). Implementation of the guidelines is delegated to local health departments under blanket authority through memoranda of agreements with the US Environmental Protection Agency. Since permit writers must consider every surface water discharge in their total management strategy, non-point source systems such as these household treatment systems may be required to meet more stringent effluent regulations. This study addresses performance of domestic treatment wetlands in meeting specific standards. Such standards are directly applicable in the US, but are relevant worldwide where similar performance criteria may eventually be required.

Surface discharging domestic treatment wetlands of the future must reduce effluent loads effectively in order to remain a viable alternative for homeowners. Numerous studies in the literature have documented overall performance and design of domestic systems (Kadlec and Knight, 1996; Mitsch and Gosselink, 2000). The literature is also replete with US case studies (AlabamaWhite and Shirk, 1998; Kentucky —Watson et al., 1990; Thom et al., 1998; Texas-Neralla et al., 2000; OhioSteer et al., 2002). Several major conclusions can be drawn from these studies. Calculations of system efficiencies using pathogen concentrations indicate that these systems display similar load reduction ranges despite widely differing climatic and geomorphologic conditions. Individually the data display large variances in the actual values while limited examples with flow meas-

Table 1

EPA surface discharge limits (maximum concentrations)

\begin{tabular}{lll}
\hline Pathogen & Concentration & Units \\
\hline Fecal Coliform & 2000 & $\mathrm{counts} / 100 \mathrm{ml}$ \\
BOD $_{5}$ & 15 & $\mathrm{mg} / \mathrm{l}$ \\
TSS & 18 & $\mathrm{mg} / \mathrm{l}$ \\
Ammonia & 1.5 & $\mathrm{mg} / \mathrm{l}$ \\
\hline
\end{tabular}

urements reduce their utility for quantitative kinetics modeling (see Mitchell and McNevin, 2001 for a review of BOD kinetics).

Design improvements or modifications necessary to meet new effluent guidelines can only be accomplished by detailed documentation of the operational characteristics of subsurface treatment wetland systems. Steer et al. (2002) reported initial results for these systems while focusing on their overall ability to reduce pathogens as compared to more mature wetlands. This study uses two additional years of data to explore the cell-tocell performance of eight domestic treatment wetlands (IDs 13-17, 19-21 from Steer et al., 2002). Since multicell wetlands are rarely reported on a cell-by-cell basis, these data serve as an example of system performance during the first 5 years of wetland development. As these systems become more widely used, compliance information will be valuable for scientists and engineers preparing watershed management plans.

\section{Methods}

\subsection{System description}

The systems cited in this study incorporated a single septic tank for primary treatment and two subsurface flow wetlands cells connected in series (Fig. 1). These wetland designs all consisted of two $25 \mathrm{~m}^{2}$ treatment cells with a depth of $0.46 \mathrm{~m}$ that employed gravity feed using a $1^{\circ}$ slope. Water level was maintained $\sim 6 \mathrm{~cm}$ below the surface through manual adjustment of inlet pipes. The substrate consisted of $\sim 3 \mathrm{~cm}$ diameter clean riverbed gravel. Runoff was prevented from entering the cells by surrounding earthen berms. The same design was used for all systems regardless of the number of occupants. The design is consistent with a conservative design for a four-occupant home based on the EPA design manual (USEPA, 2000). These systems also have similar characteristics and fall within the typical 10 $100 \mathrm{~m}^{2}$ size reported in a review of domestic wetland treatment systems (Mankin and Powell, 1998).

Several physical and operational features of these systems were unique to this study. These wetlands were constructed with the first cell sealed from the surrounding substrate to prevent infiltration into the soil column. Seven of the systems were sealed with compacted clay and one had a rubber liner. The second cells were intentionally not isolated from the natural soil, as percolation and use of the soil column was deemed as a positive element of treatment and as a means of reducing off-lot discharge. These systems are all located in the Ottawa River watershed of western Ohio, serve from 1 to 7 people, were constructed and began operation in 1998. Wetlands were planted in 1998 or 1999 using Scirpus (bulrushes) or Sagittaria (arrowhead) in the first cell 


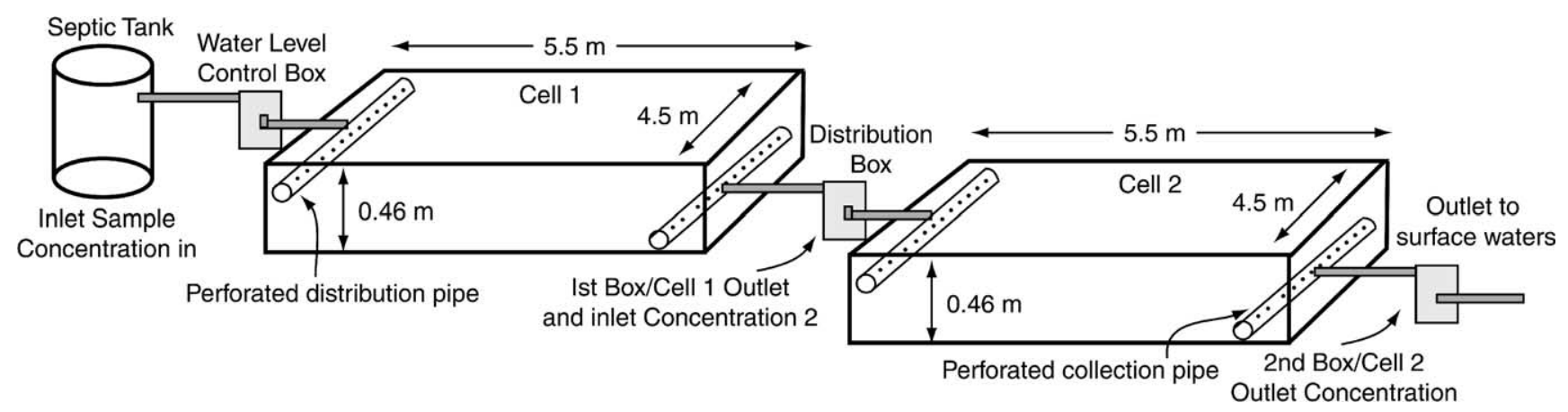

Fig. 1. Schematic diagram of wetland systems used in this study. Quarterly water quality samples were collected at the outlet to te septic tank (water control box 1), the distribution box between cells 1 and 2 and at the outlet box to cell 2 .

and ornamental wetland plants such as Acorus calamus, Lobelia cardinalis, Asclepias incarnata and Pontederia cordata in the second treatment wetland.

\subsection{Sample collection and analyses}

Water samples were collected quarterly from each wetland. Sampling began in 1999 when the wetland systems were installed as part of a local watershed-monitoring program and continued through summer 2003 (21 sample dates). Samples were collected from the septic tank, distribution box between the first and second cell, and the outlet distribution box that connects to the box that is connected to drainage tile (see Fig. 1). Grab samples were collected and analyzed to determine concentrations of fecal coliform, $\mathrm{BOD}_{5}$, ammonia, $\mathrm{NO}_{3} / \mathrm{NO}_{2}$, total nitrogen, total suspended solids and total phosphorus using standard protocols (USEPA, 1983; APHAAWWA-WPCF, 1998). Hydraulic loads of these systems were not measured. See Steer et al. (2002) for a complete description of the specific sampling procedures used to collect data for this study.

\subsection{Data reduction}

Data were binned into two groups based on household occupancy (Group 1: 1-3 or Group 2: 5-7 persons) and were edited prior to analysis. Fecal coliform counts were underestimated in these data (particularly pertinent for the inlet) because they were generally counted to a maximum $20,000 . \mathrm{BOD}_{5}$ samples that unusually exceeded $300 \mathrm{mg} / 1$ (4 of 124 samples) were removed from analyses because such high levels likely indicated a sampling error or malfunctioning septic tank. Other $\mathrm{BOD}_{5}$ samples (18/124) were removed from analyses because of dilution-related lab errors (concentrations annotated as ">"). Total suspended solid samples that were two or more orders of magnitude higher than the average value for the grouped systems (5 of 151 samples) were also removed as sampling errors. Data were neglected if "no flow" or "no access" were recorded for the entire system. In several cases, flow was conducted through one or more cells, but not through the final cell. In these cases (43/108), a value of zero was entered for the final effluent concentration for the particular cell (usually stage 3). Such cases were considered optimum performance since no effluent was released to the environment.

Average inlet, intermediate and outlet concentrations were calculated for individual systems and for groups of systems. Because of the large variance in these data, confidence intervals were reported using the standard error of the mean, $\frac{\sigma}{\sqrt{N}}$ (where $N$ is the sample size and $\sigma$ is the standard deviation). Pathogen reduction efficiencies were determined using 1-(outlet concentration/inlet concentration) with probabilities calculated using simple $t$-tests assuming equal variance. Outlet counts or concentrations were compared to suggested USEPA effluent limits for discharge to surface waters (Table 1). Per EPA sampling guidance, a sample met compliance standards if the effluent exceeded the limit during one period, but was below the limit during the next consecutive sampling period.

\section{Results}

\subsection{Fecal coliform}

Fecal coliform bacteria were reduced significantly in these systems and typically met effluent standards (Table 2). The first treatment cell reduced fecal concentrations by $\sim 83 \%$ for both occupancy groups $(p<0.00001)$. The second cell reduced the remaining concentration by $\sim 97 \%(p<0.00001)$. Total system pathogen reduction efficiencies for the systems were $99 \%$ for both groups. Average output concentrations of $1248 \pm 326$ counts $/ 100 \mathrm{ml}$ for Group 1 (low occupancy systems) systems were below the 2000 counts per $100 \mathrm{ml}$ standard. One system (ID 13) exceeded standards in $\sim 35 \%$ of the samples. Other low occupancy systems routinely met standards (in $88 \%$ or more of the samples). The average $2494 \pm 590$ counts per $100 \mathrm{ml}$ 
Table 2

Average fecal coliform count (log \# per $100 \mathrm{ml}$ ) at each sampling point, cell pathogen reduction efficiencies and system compliance rate with EPA standards

\begin{tabular}{|c|c|c|c|c|c|c|c|c|}
\hline $\begin{array}{l}\text { System ID } \\
\text { (Occupants) }\end{array}$ & $\begin{array}{l}\text { Inlet from } \\
\text { Septic }\end{array}$ & Outlet Cell 1 & $\begin{array}{l}\text { Reduction } \\
\text { Cell } 1(\%)\end{array}$ & $\begin{array}{l}\text { Cell } 2 \\
\text { Outlet }\end{array}$ & $\begin{array}{l}\text { Reduction } \\
\text { Cell } 2(\%)\end{array}$ & $\begin{array}{l}\text { Reduction } \\
\text { Aggregate }(\%)\end{array}$ & $\begin{array}{l}\text { Compliance } \\
<2000(\%)\end{array}$ & Observations $N$ \\
\hline $13(2)$ & $4.27 \pm 0.049$ & $3.59 \pm 0.42$ & 79 & $2.89 \pm 0.93$ & 80 & 96 & 65 & 21 \\
\hline $14(1)$ & $4.27 \pm 0.02$ & $3.53 \pm 0.69$ & 82 & $1.19 \pm 2.08$ & 99 & 99 & 100 & 21 \\
\hline $17(2)$ & $4.25 \pm 0.02$ & $3.47 \pm 0.48$ & 84 & $0.69 \pm 1.86$ & 99 & 99 & 100 & 18 \\
\hline $21(3)$ & $4.33 \pm 0.01$ & $3.26 \pm 0.29$ & 91 & $2.14 \pm 1.05$ & 92 & 99 & 89 & 19 \\
\hline Combined & $4.28 \pm 0.02$ & $3.47 \pm 0.47$ & 84 & $1.71 \pm 2.17$ & 98 & 99 & 88 & 79 \\
\hline $15(5)$ & $4.24 \pm 0.04$ & $3.58 \pm 0.30$ & 78 & $1.91 \pm 1.75$ & 98 & 99 & 89 & 18 \\
\hline $16(6)$ & $4.21 \pm 0.18$ & $3.59 \pm 0.41$ & 76 & $2.41 \pm 1.27$ & 93 & 98 & 86 & 21 \\
\hline $19(7)$ & $4.28 \pm 0.04$ & $3.47 \pm 0.72$ & 85 & $2.01 \pm 2.99$ & 96 & 99 & 95 & 22 \\
\hline $20(5)$ & $4.17 \pm 0.28$ & $3.24 \pm 0.68$ & 88 & $2.02 \pm 2.21$ & 94 & 99 & 95 & 20 \\
\hline Combined & $4.22 \pm 0.14$ & $3.47 \pm 0.52$ & 82 & $2.10 \pm 2.01$ & 96 & 99 & 91 & 81 \\
\hline
\end{tabular}

releases of Group 2 systems (higher occupancy) exceeded the 2000 counts per $100 \mathrm{ml}$ standard. Two of these systems (IDs 15 and 16) displayed average effluent levels below limits but exceeded the fecal standard in approximately $15 \%$ of the samples. Two (IDs 19 and 20) exceeded standards on average, but met the effluent standard in $95 \%$ of the samples.

\section{2. $\mathrm{BOD}_{5}$}

Biochemical oxygen demand reduction and compliance with standards varied significantly from system to system in the wetlands (Table 3 ). The first wetland cell reduced $\mathrm{BOD}_{5}$ by $\sim 66 \%(p<0.00001)$ for both low and high occupancy systems. The second cell reduced the remaining concentrations by $\sim 74 \% \quad(p<0.00001)$ in Group 1 systems and 59\% $(p<0.0005)$ in the Group 2 systems. Overall these systems reduced $91 \%$ (Group 1: $p<0.00001$ ) and $86 \%$ (Group 2; $p<0.00001$ ) of the $\mathrm{BOD}_{5}$. The Group 1 average output biochemical oxygen demand of $13.8 \pm 3.2 \mathrm{mg} / \mathrm{l}$ was below the $15.0 \mathrm{mg} / \mathrm{l} \mathrm{rec}-$ ommended standard. Average $\mathrm{BOD}_{5}$ concentrations for two of these systems (IDs 14 and 17) always met the standards $(100 \%$ compliance). Two other systems (IDs 13 and 21) averaged well above the standard
(24.4 \pm 12.2 and $20.9 \pm 3.0$ respectively) and failed to meet standards in more than $45 \%$ of the individual samples. Average output $\mathrm{BOD}_{5}$ concentrations for the high occupancy systems of $23.9 \pm 3.9 \mathrm{mg} / 1$ exceeded the suggested limit. One system (ID 16) displayed output levels nearly 3 times higher than all other systems.

\subsection{Total suspended solids}

Total suspended solids (TSS) were reduced effectively enough to routinely meet effluent limits (Table 4). The first cell processed $\sim 70 \%(p<0.00001)$ of the input TSS based on concentrations. The second cell played little or no role in water quality improvement as it reduced $39 \%$ (low occupancy; $p<0.1$ ) and 25\% (high occupancy; $p<0.1)$ of the remaining solids. In some systems, solids appeared to be remobilized (e.g. IDs 20 and 21). Overall these systems removed 83\% (Group 1: $p<0.00001$ ) and $77 \%$ (Group 2; $p<0.00001$ ) of the total suspended solids. Average outlet total suspended solids (TSS) of $6.37 \pm 1.42$ (Group 1) and $8.83 \pm 1.46$ (Group 2) $\mathrm{mg} / \mathrm{l}$ met OEPA/EPA standards of $18 \mathrm{mg} / 1$ (Table 4). With the exception a single system (ID 21 at $78 \%$ compliance), these wetlands met standards in almost all cases (95$100 \%$ compliance).

Table 3

Average $\mathrm{BOD}_{5}$ concentrations $(\mathrm{mg} / \mathrm{l})$ at each sampling point, cell pathogen reduction efficiencies and system compliance rate with EPA standards

\begin{tabular}{|c|c|c|c|c|c|c|c|c|}
\hline $\begin{array}{l}\text { System ID } \\
\text { (Occupants) }\end{array}$ & $\begin{array}{l}\text { Inlet from } \\
\text { Septic }\end{array}$ & Outlet Cell 1 & $\begin{array}{l}\text { Reduction } \\
\text { Cell } 1(\%)\end{array}$ & Cell 2 Outlet & $\begin{array}{l}\text { Reduction } \\
\text { Cell } 2(\%)\end{array}$ & $\begin{array}{l}\text { Reduction } \\
\text { Aggregate }(\%)\end{array}$ & $\begin{array}{l}\text { Compliance } \\
<15 \mathrm{mg} / 1(\%)\end{array}$ & Observations $N$ \\
\hline $13(2)$ & $162.2 \pm 20.8$ & $71.3 \pm 14.8$ & 56 & $24.4 \pm 12.2$ & 52 & 79 & 55 & 11 \\
\hline $14(1)$ & $131.4 \pm 16.4$ & $23.7 \pm 3.8$ & 82 & $2.6 \pm 1.1$ & 89 & 98 & 100 & 16 \\
\hline $17(2)$ & $125.6 \pm 17.6$ & $83.4 \pm 10.0$ & 34 & $4.1 \pm 2.3$ & 95 & 97 & 100 & 13 \\
\hline 21(3) & $249.5 \pm 27.1$ & $45.2 \pm 8.0$ & 82 & $20.9 \pm 3.0$ & 54 & 92 & 36 & 11 \\
\hline Combined & $162.1 \pm 11.8$ & $53.8 \pm 5.6$ & 67 & $13.8 \pm 3.2$ & 74 & 91 & 76 & 51 \\
\hline $15(5)$ & $137.9 \pm 15.5$ & $45.2 \pm 5.5$ & 67 & $14.0 \pm 3.0$ & 69 & 90 & 73 & 15 \\
\hline $16(6)$ & $173.9 \pm 18.9$ & $89.5 \pm 10.8$ & 49 & $53.3 \pm 9.1$ & 40 & 69 & 29 & 14 \\
\hline $19(7)$ & $244.2 \pm 25.8$ & $63.2 \pm 7.9$ & 74 & $10.3 \pm 4.3$ & 84 & 96 & 83 & 12 \\
\hline $20(5)$ & $141.6 \pm 15.1$ & $39.3 \pm 8.8$ & 72 & $16.7 \pm 7.4$ & 58 & 88 & 79 & 14 \\
\hline Combined & $171.2 \pm 10.7$ & $58.9 \pm 4.9$ & 66 & $23.9 \pm 3.9$ & 59 & 86 & 65 & 55 \\
\hline
\end{tabular}


Table 4

Average TSS Concentrations (mg/l) at each sampling point, cell pathogen reduction efficiencies and system compliance rate with EPA standards

\begin{tabular}{|c|c|c|c|c|c|c|c|c|}
\hline $\begin{array}{l}\text { System ID } \\
\text { (Occupants) }\end{array}$ & $\begin{array}{l}\text { Inlet } \\
\text { from Septic }\end{array}$ & Outlet Cell 1 & $\begin{array}{l}\text { Reduction } \\
\text { Cell } 1(\%)\end{array}$ & $\begin{array}{l}\text { Cell } 2 \\
\text { Outlet }\end{array}$ & $\begin{array}{l}\text { Reduction } \\
\text { Cell } 2(\%)\end{array}$ & $\begin{array}{l}\text { Reduction } \\
\text { Aggregate (\%) }\end{array}$ & $\begin{array}{l}\text { Compliance } \\
<18 \mathrm{mg} / 1(\%)\end{array}$ & Observations $N$ \\
\hline $13(2)$ & $47.28 \pm 9.63$ & $11.86 \pm 3.69$ & 75 & $5.72 \pm 0.97$ & 52 & 88 & 100 & 20 \\
\hline $14(1)$ & $25.17 \pm 5.84$ & $8.14 \pm 3.18$ & 68 & $3.25 \pm 1.81$ & 60 & 87 & 100 & 18 \\
\hline $17(2)$ & $27.84 \pm 6.82$ & $10.15 \pm 2.05$ & 64 & $5.40 \pm 4.61$ & 47 & 81 & 100 & 17 \\
\hline 21(3) & $54.41 \pm 13.65$ & $11.17 \pm 2.71$ & 79 & $12.58 \pm 3.60$ & -13 & 77 & 78 & 19 \\
\hline Combined & $38.17 \pm 4.67$ & $10.36 \pm 1.48$ & 73 & $6.37 \pm 1.42$ & 39 & 83 & 94 & 74 \\
\hline $15(5)$ & $24.81 \pm 3.09$ & $12.75 \pm 4.70$ & 49 & $7.78 \pm 2.69$ & 39 & 69 & 100 & 18 \\
\hline $16(6)$ & $45.49 \pm 5.33$ & $12.73 \pm 3.98$ & 72 & $7.51 \pm 1.85$ & 41 & 83 & 100 & 19 \\
\hline 19(7) & $38.62 \pm 6.49$ & $10.95 \pm 3.06$ & 72 & $9.01 \pm 4.07$ & 18 & 77 & 100 & 20 \\
\hline $20(5)$ & $42.13 \pm 4.35$ & $10.60 \pm 1.80$ & 75 & $10.98 \pm 3.02$ & -4 & 74 & 95 & 20 \\
\hline Combined & $37.92 \pm 2.59$ & $11.76 \pm 1.76$ & 69 & $8.83 \pm 1.46$ & 25 & 77 & 99 & 77 \\
\hline
\end{tabular}

Table 5

Average ammonia concentrations $(\mathrm{mg} / \mathrm{l})$ at each sampling point, cell pathogen reduction efficiencies and system compliance rate with EPA standards

\begin{tabular}{|c|c|c|c|c|c|c|c|c|}
\hline $\begin{array}{l}\text { System ID } \\
\text { (Occupants) }\end{array}$ & $\begin{array}{l}\text { Inlet from } \\
\text { Septic }\end{array}$ & Outlet Cell 1 & $\begin{array}{l}\text { Reduction } \\
\text { Cell } 1(\%)\end{array}$ & Cell 2 Outlet & $\begin{array}{l}\text { Reduction } \\
\text { Cell } 2\end{array}$ & $\begin{array}{l}\text { Reduction } \\
\text { Aggregate (\%) }\end{array}$ & $\begin{array}{l}\text { Compliance } \\
<1.5 \mathrm{mg} / 1(\%)\end{array}$ & Observations $N$ \\
\hline $13(2)$ & $36.84 \pm 3.95$ & $28.94 \pm 2.70$ & 21 & $18.41 \pm 2.21$ & 36 & 50 & 12 & 17 \\
\hline $14(1)$ & $31.86 \pm 2.21$ & $17.29 \pm 2.03$ & 46 & $1.96 \pm 1.17$ & 89 & 94 & 88 & 17 \\
\hline $17(2)$ & $23.32 \pm 2.34$ & $26.09 \pm 2.15$ & -12 & $3.42 \pm 1.90$ & 87 & 85 & 93 & 15 \\
\hline 21(3) & $43.67 \pm 3.08$ & $29.61 \pm 6.73$ & 32 & $12.47 \pm 1.78$ & 58 & 71 & 13 & 15 \\
\hline Combined & $33.95 \pm 1.73$ & $25.33 \pm 1.94$ & 25 & $9.14 \pm 1.23$ & 64 & 73 & 52 & 64 \\
\hline $15(5)$ & $29.52 \pm 2.80$ & $21.36 \pm 2.17$ & 28 & $8.81 \pm 1.95$ & 59 & 70 & 41 & 17 \\
\hline $16(6)$ & $40.85 \pm 2.68$ & $33.16 \pm 2.30$ & 19 & $23.38 \pm 1.98$ & 29 & 43 & 0 & 17 \\
\hline 19(7) & $42.01 \pm 4.64$ & $21.79 \pm 2.23$ & 48 & $9.13 \pm 2.22$ & 58 & 78 & 50 & 16 \\
\hline $20(5)$ & $102.01 \pm 10.54$ & $64.93 \pm 7.64$ & 36 & $33.50 \pm 7.48$ & 48 & 67 & 50 & 16 \\
\hline Combined & $53.04 \pm 4.53$ & $35.07 \pm 2.99$ & 34 & $18.63 \pm 2.35$ & 47 & 65 & 35 & 66 \\
\hline
\end{tabular}

\subsection{Ammonia}

Ammonia reduction efficiencies varied greatly from wetland to wetland and none of the systems routinely met standards (Table 5). Both cells appeared to contribute to ammonia reduction with $\sim 25-34 \%(p<0.001)$ reduced in the first cell and 47-64\% $(p<0.00001)$ of the remaining amount mitigated in the second cell. Overall these systems reduced $\sim 70 \%$ of the ammonia that entered the systems from the septic tanks. The average ammonia effluent discharged by Group 1 systems $(9.14 \pm 1.23 \mathrm{mg} / \mathrm{l})$ was over six times the $1.5 \mathrm{mg} / \mathrm{l}$ ammonia standard. Systems serving larger numbers of occupants (Group 2) had average ammonia discharge concentrations double those of Group 1 systems. Both groups of systems routinely exceeded the $1.5 \mathrm{mg} / \mathrm{l}$ ammonia standard and all but two systems (IDs 14 and 17) even exceeded the total nitrogen limit of $4.5 \mathrm{mg} / \mathrm{l}$ (OEPA, 1999) allowed for these systems. The highest performing system (ID 17) met the standard in $94 \%$ of the cases while the worst performing system (ID 16) never met the standard.

\subsection{Total phosphorus}

Total phosphorus reduction efficiencies and compliance with suggested standards varied extensively one wetland to another (Table 6). Both cells appeared to contribute to phosphorus reduction with $\sim 32-38 \%$ reduced in the first $(p<0.000001)$ and second $(p<0.001)$ cell. Overall these systems reduced $\sim 55 \%$ of the total phosphorus that entered the systems from the septic tanks. The average total phosphorus discharged by Group 1 systems $(2.79 \pm 0.40 \mathrm{mg} / \mathrm{l})$ was $\sim 70 \%$ of that discharged by the systems serving larger numbers of occupants of systems. Both groups of systems routinely exceeded the $1.5 \mathrm{mg} / 1$ standard. The highest performing system (ID 17) met the standard in $94 \%$ of the cases while the worst performing system met the standard in only $10 \%$ of the samples (ID 16).

\section{Discussion}

\subsection{Fecal coliform}

Wastewater treatment data indicated the number of residents did not impact pathogen reduction efficiency or compliance rates in these systems. The higher cell 2 processing efficiency $(\sim 97 \%)$ compared to cell $1(\sim 83 \%)$ was not significant because cell 1 inlet concentrations were under-reported (counts terminated at 20,000). Cell 2 outlet concentrations from low occupancy systems were 
Table 6

Average total phosphorus concentrations $(\mathrm{mg} / \mathrm{l})$ at each sampling point, cell pathogen reduction efficiencies and system compliance rate with EPA standards

\begin{tabular}{|c|c|c|c|c|c|c|c|c|}
\hline $\begin{array}{l}\text { System ID } \\
\text { (Occupants) }\end{array}$ & $\begin{array}{l}\text { Inlet from } \\
\text { Septic }\end{array}$ & Outlet Cell 1 & $\begin{array}{l}\text { Reduction } \\
\text { Cell } 1(\%)\end{array}$ & Cell 2 Outlet & $\begin{array}{l}\text { Reduction } \\
\text { Cell } 2\end{array}$ & $\begin{array}{l}\text { Reduction } \\
\text { Aggregate }(\%)\end{array}$ & $\begin{array}{l}\text { Compliance } \\
<1.5 \mathrm{mg} / 1(\%)\end{array}$ & Observations $N$ \\
\hline $13(2)$ & $9.96 \pm 0.69$ & $6.94 \pm 0.40$ & 30 & $6.09 \pm 0.87$ & 12 & 39 & 19 & 21 \\
\hline $14(1)$ & $5.02 \pm 0.39$ & $2.70 \pm 0.39$ & 46 & $1.61 \pm 0.57$ & 40 & 68 & 81 & 21 \\
\hline $17(2)$ & $5.80 \pm 0.57$ & $4.94 \pm 0.37$ & 15 & $0.79 \pm 0.42$ & 84 & 86 & 94 & 16 \\
\hline $21(3)$ & $7.80 \pm 0.60$ & $3.36 \pm 0.46$ & 57 & $2.11 \pm 0.54$ & 37 & 73 & 79 & 19 \\
\hline Combined & $7.22 \pm 0.36$ & $4.49 \pm 0.29$ & 38 & $2.79 \pm 0.40$ & 38 & 61 & 66 & 77 \\
\hline $15(5)$ & $5.08 \pm 0.52$ & $3.45 \pm 0.49$ & 32 & $1.58 \pm 0.37$ & 54 & 69 & 78 & 18 \\
\hline $16(6)$ & $8.02 \pm 0.62$ & $6.32 \pm 0.56$ & 21 & $6.02 \pm 0.60$ & 5 & 25 & 10 & 21 \\
\hline $19(7)$ & $6.84 \pm 0.68$ & $3.42 \pm 0.51$ & 50 & $2.89 \pm 0.82$ & 15 & 58 & 55 & 20 \\
\hline $20(5)$ & $15.41 \pm 1.1$ & $11.30 \pm 1.67$ & 27 & $5.47 \pm 1.26$ & 52 & 65 & 60 & 20 \\
\hline Combined & $8.92 \pm 0.58$ & $6.08 \pm 0.59$ & 32 & $4.08 \pm 0.46$ & 33 & 54 & 49 & 79 \\
\hline
\end{tabular}

slightly lower than those observed from the higher occupancy systems $(p<0.05)$ despite having nearly identical $(p=0.5)$ cell 2 inlet concentrations. Closer examination of the data (Table 2) indicated that these differences were minimal and had little impact on the compliance rate. Any differences in output loads are likely attributed to changes in total hydraulic loads due to evaporation and transpiration that occurred as effluent moved through cell 2. Approximately $70 \%$ of the low occupancy samples recorded no off-lot discharge from cell 2 compared to $10 \%$ of those from Group 2 systems. Evapotranspiration is a mechanism that is known to be a factor in other wetlands (Kadlec and Knight, 1996; Mitsch and Gosselink, 2000) and may have had more impact on the systems with smaller hydraulic loads (Group 1 systems). Compliance with the 2000 counts per $100 \mathrm{ml}$ standard did not appear to be related to occupancy since all systems generally met the 2000 counts per $100 \mathrm{ml}$ fecal standard. Options such as aeration in cell 2 or chlorination at the end of the cell might serve to improve system performance to the levels required to meet fecal coliform effluent standards in all cases albeit at higher cost (Steer et al., 2003).

\section{2. $\mathrm{BOD}_{5}$}

Treatment efficiency and compliance with $\mathrm{BOD}_{5}$ standards did not appear to be related to input cell concentrations or household size. The actual average $\mathrm{BOD}_{5}$ loads delivered to the two groups of wetlands were 160 $170 \mathrm{mg} / \mathrm{l}$ (Table 3). The input $\mathrm{BOD}_{5}$ concentrations to cell 1 reported here are well above the $100 \mathrm{mg} / 1$ upper limit for effective removal based on EPA sizing criteria (USEPA, 2000). Curiously, the percentage reduction of BOD $_{5}$ from the septic tank to the outlet of cell 1 and the outlet of cell 1 to the outlet of cell 2 were similar despite much lower concentrations entering the second cells (Table 3). The similar treatment efficiencies in both cells may indicate that cell one did not reach the maximum capacity to effectively treat $\mathrm{BOD}_{5}$ even when well above the design threshold. Low occupancy system
$\mathrm{BOD}_{5}$ final effluent levels were much lower than those observed for the higher occupancy systems $(p<0.05)$. However, one system (Group 2: ID 16) had significantly higher cell 2 concentrations than any of the other systems. When that system was removed from the analyses, there were no significant differences between the groups $(p=0.5)$ for outlet $\mathrm{BOD}_{5}$. System 21 (Group 1) and system 16 (Group 2) routinely exceeded standards. System 21 had some of the highest BOD $_{5}$ inlet concentrations while ID 16 had some of the highest cell 2 inlet concentrations. With these systems removed from analyses, the remaining systems complied with the $15 \mathrm{mg} / 1 \mathrm{BOD}_{5}$ limit in $\sim 80 \%$ of the cases. These low effluent concentrations and high compliance rates were expected based on studies from other regions (Bhamidimarri et al., 1991; Maehlum et al., 1995; Neralla et al., 2000).

\subsection{Total suspended solids}

These systems significantly reduced TSS in the wastewater and effectively met compliance standards for both groups of systems. There were no significant differences in input loads or individual cell treatment efficiencies between groups of systems. Inlet concentrations of TSS were approximately $1 / 3$ the suggested maximum design concentration of $100 \mathrm{mg} / 1$ (USEPA, 2000). Cell 2 efficiencies were influenced by remobilization of solids that occurred in two systems (Group 1: ID 21; Group 2: ID 20). For the remaining systems, cell 2 suspended solid outlet concentrations were statistically indistinguishable between the two groups $(p>0.05)$. On average, solids were reduced below the $18 \mathrm{mg} / 1$ limit by the time the effluent exited the first cell (Table 4). As such, systems met compliance standards in a very high percentage of the samples.

\subsection{Ammonia}

Ammonia mitigation efficiencies did not appear to be related to the number of occupants and the systems were 
not able to consistently meet standards. Two of the systems (ID 17: low occupancy; ID 20: high occupancy) disproportionately influenced average cell 1 reduction rates for these systems. System ID 17 had the lowest average inlet ammonia concentrations and actually appeared to show an increase in ammonia through cell 1. Further analysis indicated that there was no statistically significant difference between cell 1 inlet and outlet ammonia concentrations for system ID $17(p=0.2)$. Group 2 system ID 20 displayed inlet ammonia concentrations that were 2-3 times larger than observed for any other systems (Table 6). When these two systems were removed from the analyses, there was no difference in ammonia concentrations between systems at the various sample points. The reduced data for all systems combined indicated that cell 1 reduced $32 \%(p<0.00001)$ and cell 2 reduced $51 \%$ $(p<0.00001)$ of the remaining ammonia for an overall ammonia reduction of $67 \%(p<0.00001)$. These results were not unexpected based on values reported in other studies (Gersberg et al., 1986; Koottatep and Polprasert, 1997) and because subsurface treatment wetlands are known to exhibit low ammonia removal efficiencies (Hammer and Knight, 1994; Koottatep and Polprasert, 1997; Weaver et al., 2001). The low efficiencies contributed to the inability of these systems to meet the $1.5 \mathrm{mg} / \mathrm{l}$ standard. A design change that includes aeration could improve performance.

\subsection{Total phosphorus}

Total phosphorus reductions were not linked to the number of occupants and the systems were able to meet standards in the majority of the samples. One of the systems (ID 20: Group 2) displayed input phosphorus concentrations that were nearly double that of other systems. For the remaining systems, there was no difference in total phosphorus concentrations between systems at the various sample points. The reduced data for all systems combined indicated that cell 1 reduced phosphorus $36 \%(p<0.00001)$ and cell 2 reduced $30 \%$ $(p<0.0005)$ of the remaining amount for an overall phosphorus reduction of $55 \%(p<0.00001)$. The poor performance of these systems compared to the $80-97 \%$ efficiency of similar systems in other studies (Maehlum et al., 1995; Urbanc-Bercic and Bulc, 1995) is difficult to explain. System efficiency at removing $\mathrm{P}$ is related to the type of substrate (Richter and Weaver, 2003) and has been shown to decrease over time, occasionally with remobilization (Mann, 1990). Despite the low total phosphorus removal rate, systems were able to meet the $1.5 \mathrm{mg} / \mathrm{l} \mathrm{standard}$ in over $50 \%$ of the samples.

\subsection{Compliance with standards}

There is a discrepancy between current US Environmental Protection Agency compliance standards and the USEPA National Pollution Discharge Elimination Systems Total Maximum Daily Load policy. Compliance concentration standards (Table 1) that were developed to conform to USEPA (2001) guidelines can be monitored quickly, at relatively low cost and rapidly evaluated as pass or fail. However, monitoring concentrations has limited usefulness for water resource managers because total loads delivered are of key importance to the overall health of the watershed (USEPA, 2001). Flows were not measured in these systems, but larger occupancy systems more frequently discharged to surface waters than small occupancy systems. The true influence of these systems on water quality can only be fully addressed if hydraulic loading rates are determined and used in concert with effluent concentrations. A more effective method for evaluating the utility of using these systems could be developed by comparing output loads of various wastewater treatment options rather than by simply monitoring output concentrations.

\section{Conclusions}

Analyses of effluent concentrations and standards compliance from eight two-cell treatment wetlands indicated these systems effectively reduced pathogens and their discharged effluent generally met EPA suggested standards (Table 1). Fecal coliform concentrations were reduced $\sim 83 \%$ in cell one and $97 \%$ in cell 2 with high compliance rates $(\sim 90 \%)$. $\mathrm{BOD}_{5}$ concentrations were reduced with lower efficiencies than those found for fecal coliform ( $\sim 65 \%$ for cell 1 and $70 \%$ for cell 2$)$. These systems met the $15 \mathrm{mg} / 1$ standard in $\sim 2 / 3$ of the samples. Solids were reduced $\sim 70 \%$ in cell one with cell two providing much less additional water quality improvement ( $\sim 30 \%$ reduction). The two-cell design effectively met $18 \mathrm{mg} / 1$ standards showing higher than $90 \%$ compliance. Ammonia reduction was actually higher in cell $2(\sim 55 \%)$ than it was in cell $1(\sim 30 \%)$ for overall reductions of $\sim 70 \%$. The low performance of these systems in processing ammonia resulted in frequent failures to meet the $1.5 \mathrm{mg} / 1$ standard $(>50 \%)$. Total phosphorus was also not well processed in these systems on a cell-to-cell basis ( $\sim 35 \%$ for both cells 1 and 2$)$ or overall $(\sim 60 \%)$ with a correspondingly low compliance level $(\sim 55 \%)$. Additional research is needed to determine effective methods for improving ammonia and total phosphorus processing of these systems. The performance documented here suggests that trends in cell-to-cell pathogen reduction are important to understanding system performance. Additional study is needed to determine if systems with a larger surface area would be more efficient (as suggested by Stecher and Weaver (2003)) or if other design changes are required for large (5+) occupancy households. Monitoring-based regulations should be guided 
by total loads delivered to the watershed rather than by effluent concentrations.

\section{Acknowledgement}

The authors would like to acknowledge the useful reviews of several anonymous reviewers that improved this submission. We particularly wish to thank reviewer Richard Weaver of Texas A\&M for his willingness to personally discuss issues related to data reduction and system performance. The authors would like to thank the technicians who collected these data that contributed to this project. We also acknowledge that the funding to originally collect and process portions of water quality data were obtained through local governments and organizations. This publication was financed in part through a grant from the Ohio Environmental Protection Agency and the United States Environmental Protection Agency, under the provisions of Section 319(h) of the Clean Water Act.

\section{References}

APHA-AWWA-WPCF, 1998. In: Clesceri, L.S., Greenberg, A.E., Eaton, A.D. (Eds.), Standard methods for examination of water and wastewater, 20th ed. Am. Pub. Health Assoc., Washington, DC.

Bastian, R.K., Shanaghan, P., Thompson, B., 1987. Report on the use of wetlands for municipal wastewater treatment and disposal (EPA 430/09-88-005). USEPA, Washington, DC.

Bhamidimarri, R., Shilton, A., Armstrong, I., Jacobson, P., Scarlet, D., 1991. Constructed wetlands for wastewater treatment: The New Zealand experience. Water. Sci. Technel. 24 (5), 247-253.

Cronk, J.K., Fennessy, M.S., 2001. Wetland Plants: Biology and Ecology. Lewis Publishers, New York, 462 pp.

Gersberg, R.M., Elkins, B.V., Lyon, S.R., Goldman, C.R., 1986. Role of aquatic plants in wastewater treatment by artificial wetlands. Water. Res. 20 (3), 363-368.

Hammer, D.A., Knight, R.L., 1994. Designing constructed wetlands for nitrogen removal. Water. Sci. Technol. 29 (4), 15-27.

Kadlec, R.H., Knight, R.L., 1996. Treatment Wetlands. Lewis Publishers, New York, pp. 893.

Koottatep, T., Polprasert, C., 1997. Role of plant uptake on nitrogen removal in constructed wetlands located in the tropics. Water. Sci. Technol. 36 (12), 1-8.

Mann, R.A., 1990. Phosphorus removal by constructed wetlands: Substratum adsorption. In: Cooper, P.F., Findlater, B.C. (Eds.), Constructed wetlands in water pollution: Advances in water pollution control. Pergamon Press, Great Britain, pp. 97-105.

Maehlum, T., Jenssen, P.D., Warner, W.S., 1995. Cold-climate constructed wetlands. Water. Sci. Technol. 32 (3), 95-101.

Mankin, K.R., Powell, G.M., 1998. Onsite rock-plant filter monitoring and evaluation in Kansas. In: Proceedings of 8th National Symposium on Individual and Small Community Sewage Systems, ASAE, St. Joseph, Mo.

Mitchell, C., McNevin, D., 2001. Alternative analysis of BOD removal in subsurface flow constructed wetlands employing Monod kinetics. Water. Res. 35 (5), 1295-1303.
Mitsch, W.J., Gosselink, J.G., 2000. Wetlands, Third ed. Wiley, New York, pp. 936.

Neralla, S., Weaver, R.W., Lesikar, B.J., Persyn, R.A., 2000. Improvement of domestic wastewater quality by subsurface flow constructed wetlands. Biores. Technol. 75, 19-25.

Nichols, D.S., 1983. Capacity of natural wetlands to remove nutrients from wastewater. J. Water. Poll. Contr. Fed. 55, 495-505.

Nokes, R.L., Gerba, C.P., Karpiscak, M.M., 1999. Reduction of enteric organisms in small-scale, subsurface flow constructed wetlands. In: Means, J.L., Hinchee, R.E. (Eds.), Wetlands and remediation: Wastewater remediation and treatment. Battelle Press, Columbus Ohio, pp. 195-203.

OEPA, 1999. Ohio Environmental Protection Agency general permit authorization to discharge wastewater from sewage treatment systems designed to treat an average flow of 25,000 gallons per day or less under the Nation Pollution Discharge Elimination System. Columbus, $\mathrm{OH}$.

OEPA, 2001. Ohio Environmental Protection Agency general permit authorization to discharge wastewater from new and replacement household sewage treatment systems under the national pollutant discharge elimination system. Ohio Environmental Protection Agency. Columbus, $\mathrm{OH}$.

Richter, A.Y., Weaver, R.W., 2003. Treatment of domestic wastewater by subsurface flow constructed wetlands filled with gravel and tire chip media. Envron. Technol. 24, 1561-1568.

Stecher, M.C., Weaver, R.W., 2003. Effects of umbrella palms and wastewater depth on wastewater treatment in a subsurface flow constructed wetland. Environ. Technol. 24, 471-478.

Steer, D., Fraser, L., Boddy, J., Seibert, B., 2002. Efficiency of small constructed wetlands for subsurface treatment of single-family domestic effluent. Ecol. Eng. 18, 429-440.

Steer, D., Aseltyne, T., Fraser, L., 2003. Life-cycle economic model of small treatment wetlands for domestic wastewater disposal. Ecol. Econ. 44 (2-3), 359-369.

Thom, W.O., Gaddy, B.S., Ball, H.L., 1998. Long-term results of residential constructed wetlands. In: On-site wastewater treatment, Proc. 8th Annual National Sym. On Ind. and Small Community Sewage Systems, ASAE. St. Joseph, MO.

Urbanc-Bercic, O., Bulc, T., 1995. Integrated constructed wetland for small communities. Water Sci. Tech. 32 (3), 41-47.

USEPA, 1983. Methods for chemical analysis of water and wastes. (EPA 600/4-79-020) rev. Mar. 83. USEPA, Washington, DC.

USEPA, 2000. Manual: Constructed wetlands treatment of municipal wastewater. (EPA 625/R-99/010). USEPA, Washington, DC.

USEPA, 2001. Protection of the Nation's Waters through effective NPDES permits: A strategic plan. (EPA-833-R-01-001) USEPA Washington, DC.

Watson, J.T., Choate, K.D., Steiner, G.R., 1990. Performance of constructed wetland treatment systems at Benton, Hardin, and Pembrook, Kentucky during the early vegetation establishment phase. In: Cooper, P.F., Findlater, B.C. (Eds.), Constructed wetlands in water pollution: Advances in water pollution control. Pergamon Press, Great Britain, pp. 171-182.

Weaver, R.W., Lane, J.J., Johns, M.J., Lesikar, B.J., 2001. Uptake of $15 \mathrm{~N}$ by macrophytes in subsurface-flow wetlands treating domestic wastewater. Env. Tech. 22, 837-843.

White, K.D., Shirk, C.M., 1998. Performance and design recommendations for on-site wastewater treatment using constructed wetlands. In: On-site wastewater treatment, Proc. 8th Annual National Sym. On Ind. and Small Community Sewage Systems, ASAE. St. Joseph, MO.

Wood, A., 1995. Constructed wetlands in water pollution control: Fundamentals to their understanding. Water. Sci. Technol. 32 (3), $21-22$. 